77 | Ju rna | | d e a H u kum

Vol. $6 \mathrm{No} .1 \mathrm{M}$ are t 2020

Magister Hukum Universitas Jenderal Soedirman

\title{
PERLINDUNGAN HUKUM TERHADAP ANAK SEBAGAI KORBAN TINDAK PIDANA DALAM PERSPEKTIF HUKUM POSITIF INDONESIA Oleh: Purwanto ${ }^{1}$
}

\begin{abstract}
Children as creatures of God Almighty and social beings, from the womb until birth have the right to life and independence and receive protection from parents, family, society, nation and state. juridical child protection can include child legal protection in the field of civil law and in the field of public law. Every child has human rights, like the rights held by adults, not many parties think about and are willing to take concrete steps to protect children's rights. Children are very easy to become victims of all forms of violence or crime because children have not been able to do things to protect themselves properly.

This research method is used for normative legal research. The source of legal material contained in this study comes from primary, secondary, and tertiary legal materials with data collection techniques based on literature studies and data analysis techniques using deductive methods.

Based on the results of this study, it is known that legal protection of children is regulated in the Convention on the Rights of the Child, in which children's rights must be protected and guaranteed so that they can live, grow, develop, and excel in obtaining proper and quality education. For the sake of realizing child protection and welfare, institutions and regulations have been implemented which can guarantee its implementation. In Indonesia, the regulation of legal protection for children has been regulated in Law Number 23 of 2002 concerning Child Protection, then Law Number 35 of 2014 concerning Amendment to Law Number 23 of 2002 concerning Child Protection, then a second amendment has been made, namely Law No. 1 of 2016. In principle, the regulation regarding child protection is sufficiently regulated, this is based on the fact that Indonesia through Presidential Decree No. 36 of 1990 has ratified the Convention on the Rights of the Child which states the general principles of child protection, namely nondiscrimination, the best interests of children, survival and growing and respect children's participation. Thus, the UN Convention has become Indonesian law and binds all Indonesian citizens. Then the establishment of Law No. 23 of 2002 concerning Child Protection and its changes was intended as a law that generally and thoroughly regulates children's rights.
\end{abstract}

Keywords: Legal Protection, Child Protection

\section{ABSTRAK}

Anak sebagai makhluk Tuhan Yang Maha Esa dan makhluk sosial, sejak dalam kandungan sampai dilahirkan mempunyai hak atas hidup dan merdeka serta mendapat perlidungan baik dari orang tua, keluarga, masyarakat, bangsa dan negara. perlindungan anak secara yuridis dapat meliputi perlindungan hukum anak dalam bidang hukum perdata dan dalam bidang hukum publik. Setiap anak mempunyai hak asasi, sebagaimana hak yang dimiliki oleh orang dewasa, tidak banyak pihak yang turut memikirkan dan mau melakukan langkah-langkah konkret untuk melindungi hak anak. Anak mudah sekali untuk menjadi korban dari segala bentuk tindakan kekerasan ataupun kejahatan karena anak belum dapat untuk melakukan hal-hal untuk melindungi dirinya sendiri dengan baik.

Metode penelitian ini yang digunakan adalah penelitian hukum normatif. Sumber bahan hukum yang terdapat dalam penelitian ini berasal dari bahan hukum primer,

\footnotetext{
${ }^{1}$ Satpol PP, Kabupaten Banyumas
} 
sekunder, dan tersier dengan teknik pengumpulan data berdasarkan studi kepustakaan dan teknik analisis data menggunakan metode deduktif.

Berdasarkan hasil penelitian ini diketahui bahwa Perlindungan hukum terhadap anak sudah diatur dalam Konvensi Hak-hak Anak yang mana hak-hak anak harus dilindungi dan dijamin agar dapat hidup, tumbuh, kembang, dan berprestasi didalam mendapatkan pendidikan yang layak dan bermutu. Demi mewujudkan perlindungan dan kesejahteraan anak maka telah tersusun kelembagaan dan peraturan perundangan yang dapat menjamin pelaksanaannya. Di Indonesia, pengaturan perlindungan hukum terhadap anak telah diatur dalam Undang-Undang Nomor 23 Tahun 2002 tentang Perlindungan Anak, kemudian Undang-Undang Nomor 35 Tahun 2014 tentang Perubahan Atas Undang-Undang Nomor 23 Tahun 2002 tentang Perlindungan Anak, selanjutnya telah dilakukan perubahan kedua yaitu Undang-Undang Nomor 1 Tahun 2016. Pada prinsipnya pengaturan mengenai perlindungan anak sudah cukup mengaturnya, hal ini dilandasi bahwa Indonesia melalui Keputusan Presiden Nomor 36 Tahun 1990 telah meratifikasi Konvensi Hak Anak yang mengemukakan tentang prinsipprinsip umum perlindungan anak, yaitu nondiskriminasi, kepentingan terbaik bagi anak, kelansungan hidup dan tumbuh berkembang dan menghargai partisipasi anak. Dengan demikian, Konvensi PBB tersebut telah menjadi hukum Indonesia dan mengikat seluruh warga negara Indonesia. Dibentuknya Undang-Undang Nomor 23 Tahun 2002 tentang Perlindungan Anak dan perubahan-perubahannya dimaksudkan sebagai landasan hukum yang secara umum dan menyeluruh mengatur hak-hak anak.

Kata Kunci: Perlindungan Hukum, Perlindungan Anak.

\section{A. Pendahuluan}

Anak sebagai makhluk Tuhan Yang Maha Esa memiliki hak asasi sebagaimana manusia lainnya, sehingga tidak ada manusia ataupun pihak lain yang boleh merampas hak tersebut. Dalam kehidupan berbangsa dan bernegara, anak adalah masa depan bangsa dan generasi penerus cita-cita bangsa sehingga setiap anak berhak atas kelangsungan hidup, tumbuh dan berkembang, berpartisipasi serta berhak atas perlindungan dari tindak kekerasan dan diskriminasi dan kebebasan.Dalam pandangan yang visioner, anak merupakan bentuk investasi yang menjadi indikator keberhasilan suatu bangsa dalam melaksanakan pembangunan. Keberhasilan pembangunan anak akan menentukan kualitas sumber daya manusia di masa yang akan datang.

Kekerasan sering terjadi terhadap anak, yang dapat merusak, berbahaya dan menakutkan. Anak yang menjadi korban kekerasan menderita kerugian, tidak saja bersifat matertial, tetapi juga bersifat immaterial seperti goncangan emosional dan psikologis, yang dapat mempengaruhi kehidupan masa depan anak. Bentuk-bentuk kekerasan anak dapat berupa tindakan kekerasan baik secara fisik, psikis maupun seksual. ${ }^{2}$

Di dalam media massa maupun televisi begitu sering kita mendengar anak-anak yang menjadi korban kekerasan yang dilakukan terhadapnya, baik kekerasan fisik terlebih kekerasan

\footnotetext{
${ }^{2}$ Maidin Gultom, 2013, Perlindungan Hukum terhadap Anak dan Perempuan, Refika Aditama, Bandung, hlm. 2.
} 
seksual. Anak menjadi korban daripada tindakan dari mereka yang tidak bertanggung jawab. Padahal anak dalam keluarga merupakan pembawa kebahagiaan. Memelihara kelangsungan hidup anak merupakan tanggung jawab orang tua, dan hal ini tidak boleh diabaikan. Ketentuan dalam Undangundang Nomor 4 Tahun 1979 tentang Kesejahteraan Anak, merumuskan bahwa orang tua adalah yang pertamatama bertanggung jawab atas terwujudnya kesejahteraan anak baik secara rohani, jasmani, maupun sosial.

Data tahun 2018 sebagaimana dilansir oleh Republika.co.id ${ }^{3}$, menunjukan bahwa jumlah pengaduan kasus anak yang dilaporkan ke Komisi Perlindungan Anak Indonesia (KPAl) sel ama tahun 2018 tercatat sebanyak 4.885 kasus. Kasus anak berhadapan dengan hukum menduduki urutan pertama, yakni 1.434 kasus, disusul kasus terkait keluarga dan pengasuhan anak sebanyak 857 kasus. Selanjutnya, kasus pornografi dan kejahatan siber di posisi ketiga dengan 679 kasus. Di peringkat keempat, kasus pendidikan berjumlah 451 kasus. Sementara kasus kesehatan dan penyalahgunaan narkoba di posisi kelima dengan 364 kasus. Sebanyak 4.885 kasus anak

${ }^{3}$ Republika.co.id, KPAI Terima Pengaduan 4.885 Kasus Anak Selama 2018, Diakses pada tanggal 09 Januari 2019 dari https://www.republika.co.id/berita/nasional/ umum/19/01/08/pl0dj1428-kpai-terimapengaduan-4885-kasus-anak-selama2018. yang dilaporkan ke KPAl tercatat meningkat dibandingkan pengaduan kasus anak di tahun 2017 yang sebanyak 4.579 kasus. ${ }^{4}$

$$
\text { Menurut catatan Komisi }
$$

Perlindungan Anak Indonesia (KPAl), sepanjang tahun 2018, pelaku Laki-laki berjumlah 103, sedangkan pelaku berjenis kelamin perempuan, berjumlah 58 anak. $\mathrm{ABH}$ sebagai korban juga masih didominasi oleh kasus kekerasan seksual. Korban didominasi berjenis kelamin perempuan yaitu berjumlah 107 korban dan laki-laki berjumlah 75 korban. Sedangkan kasus pornografi dan siber, lebih didominasi kasus anak sebagai korban pornografi dari media sosial, yaitu mencapai 134 kasus. Korban didominasi oleh jenis kelamin perempuan. Urutan kedua kasus anak korban kejahatan seksual online, mencapai 116 kasus. Korban juga didominasi oleh anak perempuan. Korban untuk anak sebagai pelaku kepemilikan pornografi, didominasi oleh anak laki-laki, yaitu mencapai 71 anak pelaku dari 112 kasus. Jika dibandingkan tahun 2017, kasus anak sebagai korban bullying di tahun 2018 beranjak naik, begitu pula dengan kasus anak sebagai pelaku bully di media sosial, dimana tahun 2017 terdapat 73 kasus, sedangkan tahun 2018 mencapai 112 kasus. $^{5}$

\footnotetext{
${ }^{4}$ Ibid.

Komisi Perlindungan Anak Indonesia (KPAI), KPAI Sebut Pelanggaran Hak Anak
} 
Anak merupakan bagian dari generasi muda merupakan mata rantai awal yang penting dan menetukan dalam upaya menyiapkan dan mewujudkan masa depan bangsa dan negara. Anak merupakan generasi yang akan meneruskan perjuangan dan citacita seluruh bangsa di belahan bumi ini. $\mathrm{Hal}$ ini secara tegas dirumuskan dalam butir c Konsiderans Undang-Undang Nomor 35 Tahun 2014 tentang Perubahan Atas Undang-Undang nomor 23 Tahun 2002 tentang Perlindungan Anak yang berbunyi bahwa anak adalah tunas, potensi, dan generasi muda penerus cita-cita perjuangan bangsa, memiliki peran strategis dan mempunyai ciri dan sifat khusus yang menjamin kelangsungan eksistensi bangsa dan negara pada masa depan.

Anak sebagai makhluk Tuhan Yang Maha Esa dan makhluk sosial, sejak dalam kandungan sampai dilahirkan mempunyai hak atas hidup dan merdeka serta mendapat perlidungan baik dari orang tua, keluarga, masyarakat, bangsa dan negara. ${ }^{6}$ Menurut Darwan Prinst ${ }^{7}$ bahwa anak adalah bagian dari generasi muda, sebagai salah satu sumber daya

Terus Meningkat, Diakses pada tanggal 11 Januari 2019 dari http://www.kpai.go.id/berita/kpai-sebutpelanggaran-hak-anak-terus-meningkat.

6 H.R Abdussalam dan Adri Deasasfuryanto, 2014, Hukum Perlndungan Anak, PTIK, Jakarta, hlm. 1.

7 Darwan Prinst, 2003, Hukum Anak di Indonesia, Citra Aditya Bakti, Bandung, hlm. 2. manusia, merupakan potensi dan penerus cita-cita bangsa. Anak memiliki peranan startegis dalam rangka menjamin pertumbuhan fisik, mental dan sosial secara utuh, serasi, selaras dan seimbang.

Pada hakikatnya anak tidak dapat melindungi diri sendiri terhadap berbagai ancaman mental, fisik dan sosial dalam berbagai bidang kehidupan dan penghidupan. Kalau ditelusuri dengan teliti, rasa kasih sayang adalah merupakan kebutuhan psikis yang paling mendasar dalam kehidupan manusia.

Menurut Dewa Ketut Sukardi ${ }^{8}$, mengatakan bahwa:

"Apabila anak-anak pernah atau
kurang merasakan kasih sayang
orang tuanya, maka tidak bisa
dipungkiri akan menimbulkan
penderitaan batin pada anak
tersebut. Akibat adanya
penderitaan batin pada anak
karena tidak tercurahnya rasa kasih
sayang dari orang tua, akan
mengakibatkan kesehatan badan
anak terganggu, kecerdasan anak
berkurang, kelakuannya mengarah
kepada keras kepala dan nakal.
Hakikat dari pembinaan anak
sesungguhnya bersandar pada hati
nurani orang tua".

Anak menjadi kelompok yang sangat rentan terhadap kejahatan maupun kekerasan, karena anak selalu diposisikan sebagai sosok lemah atau yang tidak berdaya dan memiliki ketergantungan yang tinggi dengan

8 Dewa Ketut Sukardi, 1984, Bimbingan Perkembangan Jiwa Anak, Ghalia Indonesia, Jakarta, hlm. 63-64. 
81 | Jurnal I dea Hukum

Vol. 6 No. 1 Maret 2020

Magister Hukum Universitas Jenderal Soedirman

orang-orang dewasa di sekitarnya. Hal inilah yang membuat anak tidak berdaya saat diancam untuk tidak memberitahukan apa yang dialaminya. Hampir dari setiap kasus, pelakunya adalah orang yang dekat dengan korban (anak). Tak sedikit pula pelakunya adalah orang yang memiliki dominasi atas korban, seperti guru, paman, ayah kandung, ayah tiri, dan tetangga.

Perlindungan hukum anak atau perlindungan anak secara yuridis dapat meliputi perlindungan hukum anak dalam bidang hukum perdata dan dalam bidang hukum publik. Perlindungan anak dalam bidang hukum publik diantaranya meliputi hukum pidana materil dan hukum pidana formil.

Jika menelusuri lebih dalam tentang pengertian perlidungan anak, terlihat bahwa telah diatur dengan jelas dalam Undang- Undang Nomor 23 Tahun 2002 tentang Perlindungan Anak yang telah diubah dengan UndangUndang Nomor 35 Tahun 2014, dalam Pasal 1 angka 2 memberikan batasan perlindungan anak sebagai berikut:

"Perlindungan anak adalah segala kegiatan untuk menjamin dan melindungi anak-anak dan hakhaknya agar dapat hidup, tumbuh, berkembang, dan berpartisipasi secara optimal sesuai dengan harkat dan martabat kemanusiaan, serta mendapat perlindungan dari kekerasan dan diskriminasi".

Dari batasan tentang perlindungan anak yang diberikan oleh Pasal 1 UU No. 23 Tahun 2002 yang diubah dengan UU
No. 35 Tahun 2014 tentang Perlindungan Anak, maka anak perlu untuk dilindungi dari apapun yang akan terjadi pada dirinya.

Setiap anak mempunyai hak asasi, sebagaimana hak yang dimiliki oleh orang dewasa, tidak banyak pihak yang turut memikirkan dan mau melakukan langkah-langkah konkret untuk melindungi hak anak. Anak merupakan individu yang belum matang baik secara fisik, maupun mental apalagi sosialnya. Sehingga jika dibandingkan dengan orang dewasa, jelas anak akan lebih beresiko terhadap kekerasan. Anak mudah sekali untuk menjadi korban dari segala bentuk tindakan kekerasan ataupun kejahatan karena anak belum dapat untuk melakukan halhal untuk melindungi dirinya sendiri dengan baik.

\section{B. Metode Penelitian}

Metode Pendekatan yang digunakan Yuridis Normatif, dengan Spesifikasi Penelitian Deskriptif. Sumber Data sekunder yang terdiri dari: Bahan Hukum Primer dan Bahan Hukum Sekunder. Metode Analisa: Kualitatif.

\section{Hasil Penelitian dan Pembahasan}

\section{Pengaturan Perlindungan Hukum Terhadap Anak Sebagai Korban Tindak Pidana Dalam Perspektif Hukum Positif Indonesia}

Undang-Undang No. 23 Tahun 2002 tentang Perlindungan Anak mendefinisikan Anak adalah 
seseorang yang belum berusia 18 (delapan belas) tahun, termasuk anak yang masih dalam kandungan. Anak adalah amanah sekaligus karunia Tuhan Yang Maha Esa, yang senantiasa harus kita jaga karena dalam dirinya melekat harkat, martabat, dan hak-hak sebagai manusia yang termuat dalam Undang-Undang Dasar 1945 dan Konvensi Perserikatan Bangsa-Bangsa tentang Hak-Hak Anak dari sisi kehidupan berbangsa dan bernegara, anak adalah masa depan bangsa dan generasi penerus cita-cita bangsa.

Menurut UU Nomor 23

Tahun 2002 tentang Perlindungan

Anak Pasal 1 Butir 1

merumuskan:

"Perlindungan anak adalah segala kegiatan untuk menjamin dan melindungi anak dan hak-haknya agar dapat hidup, tumbuh, berkembang dan berpartisipasi, secara optimal sesuai dengan harkat danmartabat kemanusiaan, serta mendapatkan perlindungan dari kekerasan dan diskriminasi".

Menurut Shole Soeady dan Zhulkair: ${ }^{9}$

"Perlindungan adalah segala upaya yang ditunjukkan untuk mencegah, merehabilitasi dan memberdayakan anak-anak yang mengalami tindak perlakuan salah, eksploitasi dan pelantaran agar dapat menjamin kelangsungan hidup dan tumbuh kembang anak secara wajar, baik fisik, mental maupun sosialnya".

${ }^{9}$ Soleh Soe'aidy dan Zulkhair, 2011, Dasar Hukum Perlindungan Anak, CV. Novindo Pustaka Mandiri, Jakarta, hlm. 4.
Terdapat 10 (sepuluh) asas perlindungan anak yang diatur dalam Declaration of the Rights of the Child, yaitu $^{10}$ :

1. Anak berhak menikmati semua haknya tanpa pengecualian. Dengan kata lain, anak berhak menikmati haknya tanpa memandang perbedaan yang ada.

2. Anak berhak mendapatkan perlindungan khusus dan harus memperoleh kesempatan yang dijamin oleh hukum dan sarana lainnya.

3. Anak sejak dilahirkan berhak atas nama dan kebangsa

4. Anak berhak dan harus dijamin secara kemasyarakatan untuk tumbuh kembang secara sehat

5. Anak yang cacat fisik, mental dan lemah kedudukan sosialnya akibat suatu keadaan tertentu harus memperoleh pendidikan, perawatan dan perlakuan khusus.

6. Agar supaya kepribadian anak tumbuh secara maksimal dan harmonis, ia memerlukan kasih sayang dan pengertian.

7. Anak berhak mendapat pendidikan wajib secara cumaCuma sekurang-kurangnya di tingkat Sekolah Dasar.

8. Dalam keadaan apapun, anak harus didahulukan dalam menerima perlindungan dan pertolongan.

9. Anak harus dilindungi dari segala bentuk kekerasan, pengisapan

10.Anak harus dilindungi dari perbuatan yang mengarah ke

\footnotetext{
10 Nurini Aprilianda, Laporan Akhir Pengkajian Hukum Tentang Model Pembinaan Anak Berbasis Pendidikan Layak Anak Dalam Sistem Pemasyarakatan, Pusat Penelitian Dan Pengembangan Sistem Hukum Nasional Badan Pembinaan Hukum Nasional Kementerian Hukum Dan Hak Asasi Manusia Ri 2014, hlm. 35
} 
bentuk diskriminasi sosial, agama maupun bentuk-bentuk diskriminasi lainnya.

Adapun hak-hak anak yang tercantum dalam Undang-Undang No.23 Tahun 2002 relatif lebih lengkap dan cukup banyak dicantumkan dalam Undang-Undang Perlindungan Anak. Pasal-Pasal yang berkaitan dengan hak-hak anak tersebut adalah sebagai berikut:

1) Setiap anak berhak untuk dapat hidup, tumbuh, berkembang dan berpartisipasi secara wajar sesuai dengan harkat dan martabat kemanusiaan, serta mendapat perlindungan dari kekerasan dan diskriminasi (Pasal 4).

2) Setiap anak berhak atas suatu nama sebagai identitas diri dan status kewarganegaraan (Pasal $5)$.

3) Selain itu seorang anak berhak untuk beribadah menurut agamanya, berpikir dan berekspresi sesuai dengan tingkat kecerdasan dan usianya, dalam bimbingan orang tuanya (Pasal 6).

4) Setiap anak berhak untuk mengetahui orang tuanya, dibesarkan dan diasuh oleh orang tuanya sendiri (Pasal 7 ayat (1)). Dal am hal karena suatu sebab orang tua tidak dapat menjamin tumbuh kembang anak, atau anak dalam keadaan terlantar, maka anak tersebut berhak diasuh atau diangkat sebagai anak asuh atau anak angkat orang lain sesuai dengan ketentuan peraturan perundang-undangan yang berlaku (Pasal 7 ayat (2))

5) Setiap anak berhak memperoleh pelayanan kesehatan dan jaminan social sesuai dengan kebutuhan fisik, mental, spiritual dan sosial (Pasal 8).
6) Setiap anak berhak memperoleh pendidikan dan pengajaran dalam rangka pengembangan pribadinya dan tingkat kecerdasannya sesuai dengan minat dan bakatnya (Pasal 9 ayat (1)), selain hak anak sebagaimana dimaksud dalam ayat (1) khusus bagi anak penyandang cacat juga berhak memperoleh pendidikan luar biasa, sedang bagi anak yang memiliki keunggulan juga berhak mendapatkan pendidikan khusus (Pasal 9 ayat (2)).

7) Setiap anak berhak menyatakan dan didengar pendapatnya, menerima, mencari dan mendapatkan informasi sesuai dengan tingkat kecerdasan dan usianya demi pengembangan dirinya sesuai dengan nilai -nilai kesusilaan dan kepatutan (Pasal 10).

8) Setiap anak berhak untuk beristirahat dan memanfaatkan waktu luang, bergaul dengan anak yang sebaya, bermain, berekreasi, berkreasi sesuai dengan bakat, minat, dan tingkat kecerdasannya demi perkembangan diri (Pasal 11).

9) Setiap anak penyandang cacat berhak memperoleh rehabilitasi, bantuan sosial, dan pemeliharaan taraf kesejahteraan sosial (Pasal 12)

10) Setiap anak dalam masa pengasuhan orang tua, wali, atau pihak lain manapun yang bertanggung jawab atas pengasuhan, berhak mendapat perlindungan dari perlakuan diskriminasi, eksploitasi, penelantaran, kekejaman, kekerasan, penganiayaan, ketidakadilan, dan perlakuan salah lainnya (Pasal 13 ayat (1)), dalam hal orang tua, wali, atau pengasuh anak dalam melakukan segala bentuk perlakuan sebagaimana dimaksud dalam ayat (1), maka pelaku dikenakan pemberatan hukuman (Pasal 13 ayat (2)). 
11) Setiap anak berhak untuk diasuh oleh orang tuanya sendiri, kecuali jika ada alasan dan/atau aturan hukum yang sah menunjukkan bahwa pemisahan itu adalah demi kepentingan terbaik bagi anak dan merupakan pertimbangan terakhir (Pasal 14).

12) Setiap anak berhak memperoleh perlindungan dari penyalahgunaan dalam kegiatan politik, pelibatan dalam sengketa bersenjata, pelibatan dalam kerusuhan sosial, pelibatan dalam masalah yang mengandung kekerasan, dan pelibatan dalam peperangan (Pasal 15).

13) Setiap anak berhak memperoleh perlindungan dari sasaran penganiayaan, penyiksaan, dan penjatuhan hukuman yang tidak manusiawi (Pasal 16 ayat (1)), setiap anak berhak mendapatkan kebebasan sesuai hukum (ayat (2)), penangkapan, penahanan, atau tindak pidana penjara anak hanya dilakukan apabila sesuai dengan hukum yang berlaku dan hanya dapat dilakukan sebagai upaya terakhir (ayat (3)).

14) Setiap anak yang dirampas kebebasannya berhak untuk mendapat perlakuan secara manusiawi dan penempatan dipisahkan dari orang dewasa, memperoleh bantuan hukum atau bantuan lainnya secara efektif dalam setiap tahapan upaya hukum yang berlaku, dan membela diri dan memperoleh keadilan didepan pengadilan anak yang obyektif dan tidak memihak dalam sidang tertutup untuk umum (Pasal 17 ayat (1)), setiap anak yang menjadi korban atau pelaku kekerasan seksual atau yang berhadapan dengan hukum berhak untuk dirahasiakan (ayat (2)).

15) Setiap anak yang menjadi korban atau pelaku tindak pidana berhak mendapatkan bantuan hukum dan bantuan lainnya (Pasal 18). Perlindungan anak yang berhadapan dengan hukum juga termuat dalam Pasal $66 \quad$ Undang-Undang Nomor 39 Tahun 1999 tentang Hak Asasi Manusia:

a. Setiap anak berhak untuk tidak dijadikan sasaran penganiayaan, penyiksaan, atau penjatuhan hukuman yang tidak manusiawi.

b. Hukuman mati atau hukuman seumur hidup tidak dapat dijatuhkan untuk pelaku tindak pidana yang masih anak.

c. Setiap anak berhak untuk tidak dirampas kebebasannya secara melawan hukum.

d. Penangkapan, penahanan, atau pidana penjara anak hanya boleh dilakukan sesuai dengan hukum yang berlaku dan hanya dapat dilaksanakan sebagai upaya terakhir.

e. Setiap anak yang dirampas kebebasannya berhak mendapatkan perlakuan secara manusiawi dan dengan memperhatikan kebutuhan pengembangan pribadi sesuai dengan usianya dan harus dipisahkan dari orang dewasa, kecuali demi kepentingannya.

f. Setiap anak yang dirampas kebebasannya berhak memperoleh bantuan hukum atau bantuan lainnya secara efektif dalam setiap tahapan upaya hukum yang berlaku.

g. Setiap anak yang dirampas kebebasannya berhak untuk membela diri dan memperoleh keadilan di depan Pengadilan Anak yang obyektif dan tidak memihak dalam sidang yang tertutup untuk umum.

Materi Hukum mengenai hak-hak anak dalam Konvensi Hak Anak tersebut, dapat dikelompokkan dalam 4 (empat) kategori hak-hak anak yaitu: 
85 | Jurnal Idea Hukum

Vol. $6 \mathrm{No} .1 \mathrm{Maret} 2020$

Magister Hukum Universitas Jenderal Soedirman

a. Hak terhadap kelangsungan hidup (survival rights); Yaitu hak-hak anak dalam Konvensi Hak Anak yang meliputi hak-hak untuk melestarikan dan mempertahankan hidup (the rights of life) dan untuk memperoleh standar kesehatan tertinggi dan perawatan yang sebaik-baiknya (the rights to the higest standart of health and medical care attainable). Hak terhadap kelangsungan hidup di dalam Konvensi Hak Anak terdapat pada pasal 6 dan pasal 24 Konvensi Hak Anak. Dalam pasal 6 Konvensi Hak Anak tercantum ketentuan yang mewajibkan kepada setiap negara peserta untuk menjamin kelangsungan hak hidup (rights to life), kelangsungan hidup dan perkembangan anak (the survival and development of the child).

Pasal 24 Konvensi Hak Anak selengkapnya mengatur mengenai kewajiban negara-negara peserta untuk menjamin hak atas taraf kesehatan tertinggi yang bisa dijangkau dan untuk memperoleh pelayanan kesehatan dan pengobatan, khususnya perawan kesehatan primer (rights to the child enjoyment of the high test attainable standart of health and facilities for the treatment of illness and rehabilitation health). Mengenai hak terhadap kelangsungan hidup (survival rights) dalam Konvensi Hak Anak berkaitan pula dengan beberapa pasal yang relevan dengan hak kelangsungan hidup (survival rights) itu, pasal-pasal tersebut yang mengatur mengenai hak anak yakni :

a. Pasal 8, mengatur tentang kewajiban negara untuk melindungi dan bilamana perlu, memulihkan aspek dasar jati diri seorang anak, (nama kewarganegaraan dan ikatan keluarga)

b. Pasal 9, mengatur tentang hak anak untuk hidup bersama orang tuanya, kecuali kalau hal ini dianggap tidak sesuai dengan kepentingan terbaiknya. Hak anak untuk mempertahankan hubungan dengan keduanya orang tuanya jika terpisah dari salah satu atau keduanya. Kewajiban negara dalam kasus dimana pemisahan seperti itu terjadi akibat tindakan negara.

c. Pasal 19, mengatur tentang kewajiban negara untuk melindungi anak-anak dari segala bentuk salah perlakuan (abuse) yang dilakukan oleh orang tua atau orang lain yang bertanggung jawab atas pengasuhan mereka untuk menyelenggarakan programprogram pencegahan dan perawatan sehubungan dengan hal ini;

d. Pasal 20,mengatur tentang kewajiban negara untuk memberikan perlindungan khusus bagi anak-anak yang kehilangan lingkungan keluarga mereka serta untuk menjamin tersedianya alternatif pengasuhan keluarga atau penempatan institusional yang sesuai bagi mereka dengan mempertimbangkan latar budaya anak 
e. Pasal 21, mengatur tentang adopsi dimana di negaranegara peserta dimana adopsi diakui dan/atau diperbolehkan, adopsi hanya akan dilakukan demi kepentingan terbaik bagi anak, dengan segala perlindungan yang perlu bagi anak yang disahkan oleh pejabat yang berwewenang;

f. Pasal 26, mengatur tentang hak anak atas tunjangan dari jaminan sosial;

g. Pasal 28, mengatur tentang hak-hak anak atas pendidikan dan kewajiban negara untuk menjamin agar setidaknya pendidikan dasar diadakan secara cuma-cuma dan berlaku wajib. Penyelenggaraan disiplin sekolah harus mencerminkan martabat kemanusiaan anak. Penekanan diletakkan pada perlunya kerja sama internasional guna menjamin hak ini;

h. Pasal 30, mengatur tentang hak-hak anak dari kelompok masyarakat minoritas dan penduduk asli untuk hidup dalam alam budaya serta mengamalkan dan menggunakan bahasa mereka sendiri;

i. Pasal 32, mengatur tentang kewajiban negara untuk melindungi anak-anak dari keterlibatan dalam pekerjaan yang mengancam kesehatan, pendidikan atau perkembangan mereka, untuk menetapkan batas usia minimum untuk bekerja, serta menetapkan aturan bagi kondisi kerja;

j. Pasal 34, mengatur tentang hak anak atas perlindungan dari eksploitasi dan penganiayaan seksual, termasuk prostitusi dan keterlibatan

dalam pornografi;

k. Pasal 35, mengatur tentang kewajiban negara untuk menjalani segala upaya guna mencegah penjualan, penyelundupan dan penculikan anak;

I. Pasal 38 , mengatur tentang kewajiban negara untuk menghormati dan menjamin dihormatinya UU kemanusiaan yang berlaku bagi anak-anak.

b. Hak terhadap perlindungan (protection rights); yaitu hak-hak anak dalam Konvensi Hak Anak yang meliputi hak perlindungan dari diskriminasi, tindak kekerasan dan keterlantaran bagi anak yang tidak mempunyai keluarga bagi anak-anak pengungsi. $^{11}$

c. Hak untuk tumbuh berkembang (development right); yaitu hak-hak anak dalam Konvensi Hak Anak yang meliputi segala bentuk pendidikan (formal dan non formal) dan hak untuk mencapai standar hidup yang layak bagi perkembangan fisik, mental, spiritual, moral dan sosial anak. ${ }^{12}$ Menurut pasal 28 ayat 1 Konvensi Hak Anak, yang menyebutkan hak anak untuk mendapatkan pendidikan dan sekaligus memberikan langkah konkret untuk terselenggaranya hak terhadap pendidikan.

\footnotetext{
${ }^{11}$ Ibid.

${ }^{12}$ Ibid., hlm. 35.
} 
87 IJurnal Idea Hukum

Vol. 6 No. 1 Maret 2020

Magister Hukum Universitas Jenderal Soedirman

d. Hak untuk berpartisipasi (participation rights), yaitu hakhak anak dalam Konvensi Hak Anak yang meliputi hak anak untuk menyatakan pendapat dalam segala hal yang mempengaruhi anak (the rights of a child to express her/his views in alimetters affecting that child). Dalam Pasal 12 Konvensi Hak Anak diatur bahwa negara peserta menjamin hak anak untuk menyatakan pendapat, dan untuk memperoleh pertimbangan atas pendapatnya itu, dalam segala hal atau prosedur yang menyangkut diri si anak.

Selain hak-hak anak yang terdapat dalam konvensi anak di atas, hak anak juga di atur secara spesifik di dalam Peraturan Pemerintah Pengganti UU Republik Indonesia Nomor 1 Tahun 2016 Tentang Perubahan Kedua Atas UU Nomor 23 Tahun 2002 Tentang Perlindungan Anak.Sebagaimana telah diuraikan sebelumnya, bahwa anak mempunyai kedudukan yang sangat strategis dalam bahasa, negara, masyarakat maupun keluarga. Anak merupakan tumpuan harapan masa depan bagi bangsa, negara, masyarakat ataupun keluarga. Oleh karena kondisinya sebagai anak, maka perlu perlindungan khusus agar dapat tumbuh dan berkembang secara wajar baik fisik, mental, dan rohaninya.bergabung dan dengan bebas mengekspresikan diri sendiri. Selain di atur mengenai hak-hak anak, diatur pula kewajiban anak yaitu setiap anak berkewajiban untuk menghormati orang tua, wali, guru, mencintai keluarga, masyarakat, dan menyayangi teman, mencintai tanah air, bangsa dan negara, menunaikan ibadah sesuai dengan ajaran agamanya dan melaksanakan etika dan akhlak yang mulia

Tujuan dari perlindungan anak berdasarkan Pasal 3 Undang-Undang Perlindungan Anak adalah untuk menjamin terpenuhinya hak -hak anak agar dapat hidup, tumbuh, berkembang, dan berpatisipasi secara optimal sesuai dengan harkat dan martabat kemanusiaan, serta mendapat perlindungan dari kekerasan dan diskriminasi, demi terwujudnya anak Indonesia yang berkualitas, berakhlak mulia, dan sejahtera. Jika keluarga melakukan kekerasan dan beresiko menjadi sasaran kekerasan, semua bantuan harus diberikan untuk membantu orang tua menangani keluarga mereka secara lebih aman. Dalam hal ini mungkin dibutuhkan kelas-kelas tertentu untuk orang tua, penyuluhan untuk mengurangi kemungkinan terjadinya tindak kekerasan lebih lanjut. Dalam perlindungan anak diharapkan semua 
lapisan masyarakat turut serta, sehingga tidak terjadi keterlantaran seperti yang termuat dalam Pasal 72.

Sementara itu supaya perlindungan anak berguna dan berhasil seperti yang ada dalam Undang-Undang No.23 Tahun 2002 tentang perlindungan anak, perlindungan hukum bagi kehidupan anak harus memenuhi syarat-syarat sebagai berikut:

1) Faktor ekonomi dan sosial yang dapat menunjang keluarga anak,

2) Nilai budaya yang memberi kebebasan bagi pertumbuhan anak,

3) Solidaritas anggota keluarga dan masyarakat untuk meningkatkan kehidupan anak.

Pasal 13 Undang-Undang No.23 Tahun 2002 menyatakan setiap anak dalam pengasuhan orang tua, wali atau pihak lain manapun yang bertanggung jawab atas pengasuhan, berhak mendapat perlindungan dari perlakuan:

1) Diskriminasi,

2) Eksploitasi, baik ekonomi maupun seksual,

3) Penelantaran,

4) Kekejaman, kekerasan, dan penganiayaan,

5) Ketidakadilan, dan

6) Perlakuan salah yang lain.

Secara garis besar, perlindungan anak dapat dibedakan menjadi 2 (dua) sifat, yaitu perlindungan yang bersifat yuridis dan perlindungan yang bersifat non yuridis. Perlindungan yang bersifat yuridis adalah perlindungan yang menyangkut semua aturan hukum yang mengatur kehidupan anak langsung bagi seorang anak, dalam arti semua aturan hukum yang mengatur kehidupan anak. Perlindungan yang bersifat yuridis meliputi perlindungan dalam bidang hukum publik dan hukum keperdataan, sedangkan perlindungan yang bersifat non yuridis meliputi bidang so sial, kesehatan, pendidikan. ${ }^{13}$

2. Ketentuan Hukum Positif Yang Mengatur Tentang Perlindungan Hukum Terhadap Anak Sebagai Korban Tindak Pidana Yang Sekarang Ada Sudah Cukup Mengatur

Undang-Undang Perlindungan

Anak dibentuk sebagai hasil dari

Politik Hukum Pemerintahan, di mana hal ini menjelaskan bahwa politik hukum bagian dari ilmu hukum yang mengkaji perubahan ius constituendum menjadi ius constitutum untuk memenuhi kehidupan perubahan masyarakat. Untuk memahami perubahan kehidupan masyarakat itu perlu ditelaah apakah pengertian perubahan, pengertian kehidupan, dan pengertian masyarakat.

Berkaitan dengan pembentukan Undang-Undang

13 Soemitra, 1990, Aspek Hukum Perlindungan Anak, Bumi Aksara, Jakarta, hlm. 13. 
setelah Amandemen UUD 1945 dan
sebelum maupun sudah
ditetapkannya Undang-Undang
Nomor 12 Tahun 2011 tentang
Pembentukan Peraturan Perundang-
Undangan, maka proses pembentukan Undang-Undang masih dihadapkan pada berbagai problematik, baik secara substansial maupun dari segi teknis yuridis penyusunan, maupun pelaksanaan dan penegakan hukumnya. ${ }^{14} \mathrm{Hal}$ ini juga berlaku dalam pembentukan perlindungan anak, sampai dengan disahkannya UU 17/2016, sebagai perubahan kedua atas UndangUndang Perlindungan Anak.

Meskipun Undang-Undang Nomor 39 tahun 1999 Tentang Hak Asasi Manusia telah mencantumkan secara rinci tentang hak anak, namun pelaksanaan kewajiban dan tanggung jawab orang tua, keluarga, masyarakat dan Pemerintah untuk memberikan perlindungan pada anak masih memerlukan suatu undangundang mengenai perlindungan anak sebagai landasan yuridis bagi pelaksanaan kewajiban dan tanggung jawab tersebut. M. Junus Lamuda menyatakan sangat

14 Yuliandri, 2008, Membentuk UndangUndang Yang Berkelanjutan, di dalam: Siti Sundari Rangkuti, Dinamika Hukum Tata Negara dan Hukum Lingkungan (Edisi Khusu Kumpulan Tulisan Dalam Ragka Purnabakti Pror. Dr. Siti Sundari Rangkuti $\mathrm{SH}$ ), Airlangga University Press, Surabaya, hlm. 281. diperlukan pembentukan undangundang ini didasarkan pada pertimbangan, bahwa perlindungan anak dalam segala aspeknya merupakan bagian dari kegiatan pembangunan nasional, khususnya dalam memajukan kehidupan bangsa dan negara. ${ }^{15}$

Sejatinya undang-undang yang berkaitan dengan perlindungan anak ini sudah ada pada tahun 1979 dengan keluarnya Undang-Undang nomor 4 Tahun 1979 tentang Kesejahteraan Anak. Undangundang ini merupakan salah satu bentuk dari keprihatinan pemerintah terhadap perlindungan anak di Indonesia. Arief Ghosita $^{16}$ menyatakan bahwa kesejahteraan anak adalah hak asasi anak yang diusahakan bersama. Pelaksanaan pengadaan kesejahteraan bergantung pada partisipasi yang baik antara objek dan subjek dalam usaha pengadaan kesejahteraan anak tersebut. Setiap anggota masyarakat dan pemerintah (yang berwajib) berkewajiban ikut serta dalam pengadaan kesejahteraan anak dalam suatu masyarakat yang merata akan membawa akibat yang baik pada keamanan dan stabilitas

\footnotetext{
15 Risalah Perundangan-Undangan Pembentukan Undang-Undang Nomor 23 Tahun 2002 Tentang Perlindungan Anak, hlm. 19

16 Arief Ghosita, 2004, Masalah-Masalah Perlindungan Anak, PT. Bhuana IImu Populer, Jakarta, hlm. 35-36.
} 
suatu masyarakat, yang selanjutnya akan mempengaruhi pembangunan yang sedang diusahakan dalam masyarakat tersebut. Oleh sebab itu usaha pengadaan kesejahteraan anak sebagai suatu segi perlindungan anak mutlak harus dikembangkan.

Di dunia Internasional instrumen hukum yang mengatur perlindungan hak-hak anak terdapat dalam konvensi Perserikatan Bangsa-Bangsa (PBB) tentang hakhak anak (Convention on the Rights of the Child) tahun 1989, yang telah diratifikasi oleh lebih dari 191 Negara. Pada tahun 1990 untuk lebih menghargai dan melindungi anak, maka pada tahun 1990 Indonesia melalui Keputusan Presiden Nomor 36 Tahun 1990 meratifikasi Konvensi Hak Anak yang mengemukakan tentang prinsip-prinsip umum perlindungan anak, yaitu nondiskriminasi, kepentingan terbaik bagi anak, kelansungan hidup dan tumbuh berkembang dan menghargai partisipasi anak. Dengan demikian, Konvensi PBB tersebut telah menjadi hukum Indonesia dan mengikat seluruh warga negara Indonesia. ${ }^{17}$

Pada prinsipnya Indonesia dalam hal pengaturan perlindungan

17 Rika Saraswati, 2015, Hukum Perlindungan Anak di Indonesia, Citra Aditya Bakti, Bandung, hlm. 15. anak sudah cukup mengaturnya.

Pada tahun 2002 pemerintah mengeluarkan Undang-Undang Nomor 23 Tahun 2002 tentang Perlindungan Anak (UU 23/2002), undang-undang ini dimaksudkan sebagai undang-undang payung (umbrella's law) yang secara sui generis mengatur hak-hak anak. Namun dalam konsiderans hukumnya justru tidak mencantumkan Konvensi Hak Anak (KHA) sebagai referensi yuridis. Sumber kesekahannya terletak pada landasan hukum ratifikasi KHA yang menggunakan instrumen hukum keputusan presiden yang secara hierarki lebih derajatnya daripada undang-undang. Meskipun demikian, substansi KHA dapat diadopsi sebagai materi undang-undang, seperti penggunaan asas dan tujuan perlindungan anak yang di dalam undang-undang tersebut. ${ }^{18}$

Maidin Gultom menyatakan bahwa UU 23/2002 menjelaskan bahwa perlindungan anak adalah segala kegiatan untuk menjamin dan melindungi anak dan hak-haknya agar tetap hidup untuk menjamin dan melindungi anak dan hak-haknya agar tetap hidup, tumbuh, berkembang dan berpartisipasi secara optimal sesuai dengan harkat dan martabat kemanusiaan, serta mendapat perlindungan dari

${ }^{18}$ Ibid. 
91 IJurnal Idea Hukum

Vol. 6 No. 1 Maret 2020

Magister Hukum Universitas Jenderal Soedirman

kekerasan dan diskriminasi.

Perlindungan anak dapat juga diartikan sebagai segala upaya yang ditujukan untuk mencegah, rehabilitasi dan memberdayakan anak yang mengalami tindak perlakuan salah, eksploitasi dan penelantaran, agar dapat menjamin kelangsungan hidup dan tumbuh kembang secara wajar, baik fisik, mental maupun sosialnya. Perlindungan anak adalah suatu usaha melindungi anak agar dapat melaksanakan hak dan kewajibannya. $^{19}$ Kebijaksanaan, usaha dan kegiatan yang menjamin terwujudnya perlindungan anak, pertama didasarkan atas pertimbangan bahwa anak-anak merupakan golongan yang rawan dan dependent, di samping itu, karena adanya golongan anak-anak yang mengalami hambatan dalam pertumbuhan dan perkembangannya, baik rohani, jasmani maupun sosial.

$$
\text { Dasar }
$$

pelaksanaan perlindungan anak UU 23/2002 itu sendiri menurut Maidin Gultom adalah: ${ }^{20}$ a) dasar filosofis, Pancasila sebagai dasar kegiatan dalam berbagai bidang kehidupan keluarga, bermasyarakat, bernegara, dab berbangsa, dan dasar filosofis

19 Maidin Gultom, 2012, Perlindungan Hukum Terhadap Anak dan Perempuan, Refika Aditama, Bandung, hlm, 70

${ }^{20}$ Ibid. pelaksanaan perlindungan anak; b) dasar etis, pelaksanaan perlindungan anak harus sesuai dengan profesi yang berkaitan, untuk mencegah perilaku menyimpang dalam pelaksanaan kewenangan, kekuasaan dan kekuatan dalam pelaksanaan perlindungan anak; c) dasar yuridis, pelaksanaan perlindungan anak harus didasarkan pada UUD 1945 dan berbagai peraturan perundang-undangan lainnya yang berlaku. Penerapan dasar yuridis ini harus sesuai secara integratif, yaitu penerapan terpadu menyangkut peraturan perundangundangan dari berbagai bidang hukum yang berkaitan.

Perkembangan pengaturan perlindungan anak kembali mendapatkan angin segar pada tahun 2014, hal ini ditandai dengan pemerintah mengadakan perubahan dan penambahan terhadap UU 23/2002 melalui Undang-Undang nomor 35 Tahun 2014 tentang Perubahan Atas Undang-Undang Nomor 23 Tahun 2002 tentang Perlindungan Anak (UU 35/2014), yang telah berlaku sejak diundangkannya, yaitu pada tanggal 17 Oktober 2014. Penambahan substansi dalam UU 35/2014, di antaranya penambahan definisi kekerasan, perlindungan hak-hak anak dari segala bentuk kekerasan di satuan pendidikan, pemenuhan hak 


anak untuk tetap bertemu dan
berhubungan pribadi dengan kedua
orang tuanya setelah terjadi
perceraian, larangan untuk
memperlakukan anak secara
diskriminatif dan segala bentuk
kekerasan. $^{21}$

Perubahan dan penambahan terhadap UU 23/2002 ini agar perlindungan anak selama ini belum dapat berjalan dengan aktif, karena masih adanya tumpang tindih antar peraturan perundang-undangan sektoral terkait dengan definisi anak. Di sisi lain, maraknya kejahatan terhadap anak di masyarakat, salah satunya adalah kejahatan seksual, memerlukan peningkatan komitmen dari pemerintah, pemerintah daerah dan masyarakat serta semua pengangku kepentingan yang terkait dengan penyelengaraan perlindungan anak. Untuk efektivitas pengawasan penyelenggaraan perlindungan anak diperlukan lembaga independen yang diharapkan dapat mendukung pemerintah dan pemerintah daerah dalam penyelenggaraan perlindungan anak. Di dalam penjelasan UU 35/2014, merumuskan bahwa perubahan ini mempertegas perlunya pemberatan sanksi pidana dan denda bagi pelaku kejahatan terhadap anak, untuk memberikan efek jera, serta mendorong adanya langkah konkret untuk memulihkan kembali fisik, psikis, dan sosial anak korban dan/atau anak pelaku kejahatan, Hal tersebut perlu dilakukan untuk mengantisipasi anak korban dan/atau anak pelaku kejahatan di kemudian hari tidak menjadi pelaku kejahatan yang sama.

Memang jumlah kekerasan pada anak khususnya kekerasan seksual terus meningkat, terutama di tahun 2016 banyak sekali pemberitaan kekerasan seksual terhadap anak. Contohnya saja, anak diperkosa oleh orangtuanya, anak diperkosa oleh orangtua tirinya, anak diperkosa oleh saudaranya, anak diperkosa oleh keluarganya, anak diperkosa oleh temannya, bahkan anak perempuan diperkosa oleh beberapa orang yang melibatkan laki-laki dewasa ataupun laki-laki yang masih dikategorikan anak diabawah umur. Kondisi demikian mendorong banyak pihak, terutama para pemerhati perlindungan anak mendesak pemerintah untuk menerbitkan peraturan pemerintah pengganti undang-undang (Perppu) untuk mengubah undang-undang perlindungan anak. Presiden Joko Widodo pun merespon dengan cepat tuntutan tersebut dengan menetapkan Perppu Nomor 1 Tahun 2016 tentang Perubahan Kedua

${ }^{21}$ Rika Saraswati, Op. Cit, hlm. 15-16 
Undang-Undang Nomor 23 Tahun 2002 tentang Perlindungan Anak.

Pada tanggal 25 Mei 2016, Presiden Joko Widodo (Jokowi) telah menandatangani Perppu Nomor 1 Tahun 2016. Perppu yang sering disebut dengan Perppu Kebiri ini merupakan Perppu pertama yang dikeluarkan di masa Pemerintahan Jokowi, setelah lama diperdebatan. Sebagian pihak menyambut baik langkah Jokowi menerbitkan Perppu ini. Sebab hal itu dipandang sebagai bentuk keseriusan Pemerintah dalam hal mengatasi kondisi darurat kejahatan seksual terhadap anak. Terlebih kasus kejahatan seksual terhadap Anak di Indonesia dari hari ke hari semakin meningkat. Korban tidak hanya diperkosa, tetapi juga disiksa, dibunuh, bahkan dimutilasi. Oleh karena itu menurut Jokowi, kejahatan seksual pantas disebut sebagai kejahatan yang luar biasa (extraordinary crime). Sehingga membutuhkan penanganan khusus atau cara-cara kusus untuk mengatasinya. $^{22}$ Salah satunya melalui pemberatan sanksi bagi pelaku dengan sanksi kebiri sebagai salah satu hukuman tambahan yang diatur dalam Perppu ini. Kemudian Perppu tersebut menjadi undang-

22 Zihan Syahayani, Problematika Perppu Kebiri, Diakses pada tanggal 25 Maret 2019 dari http://www.theindonesianinstitute.com/probl ematika-perppu-kebiri/. undang Nomor 1 Tahun 2016 tentang perubahan kedua UndangUndang Nomor 23 Tahun 2002 tentang Perlindungan Anak (UU 1/2016).

Perppu ini mengubah dua
pasal dari undang-undang
sebelumnya, yakni pasal 81 dan 82 ,
serta menambah satu pasal $81 \mathrm{~A}$.
Berikut ini isi dari Perppu Nomor 1 Tahun 2016: Pasal 81 ayat (1) menyatakan bahwa setiap orang yang melanggar ketentuan sebagaimana dimaksud dalam Pasal 76D dipidana dengan pidana penjara paling singkat 5 (lima) tahun dan paling lama 15 (lima belas) tahun dan denda paling banyak Rp5.000.000.000,00 (lima miliar rupiah). Menjadi catatan, bahwa Pasal 76D Undang-Undang 23 tahun 2004 tentang Penghapusan Kekerasan Dalam Rumah Tangga (UU KDRT) menyatakan bahwa setiap orang dilarang melakukan kekerasan atau ancaman kekerasan memaksa anak melakukan persetubuhan dengannya atau dengan orang lain. Sedangkan hukuman pidana pada UU KDRT sebelumnya adalah paling singkat tiga tahun dan paling lama 15 tahun. Adapun nominal denda sebelumnya berkisar Rp 60 juta hingga Rp 300 juta.

Atas pengesahan pengaturan itu, penjelasan dari pihak pemerintah 


\begin{abstract}
masih kurang jelas terkait implementasi hukuman tambahan UU 1/2016 tersebut. Kalau pun harus setuju, maka catatan yang terpenting bahwa Perppu ini akan direvisi, maka harus dibuat undang-undang yang lebih komprehensif dan bisa menjawab persoalan bangsa, khususnya anak dan perempuan. Hal ini agar kedepan tidak terjadi tumpang tindih terkait perlindungan anak, agar kepastian perlindungan anak semakin jelas dan semakin pasti didalam menjaga generasi penerus bangsa ini..
\end{abstract}

\section{Simpulan dan Saran}

\section{a. Simpulan}

1. $\mathrm{Di}$ Indonesia, pengaturan perlindungan hukum terhadap anak telah diatur dalam Undang-Undang Nomor 23 Tahun 2002 tentang Perlindungan Anak, kemudian Undang-Undang Nomor 35 Tahun 2014 tentang Perubahan Atas UndangUndang Nomor 23 Tahun 2002 tentang Perlindungan Anak, selanjutnya telah dilakukan perubahan menjadi UndangUndang Republik Indonesia Nomor 17 Tahun 2016 Tentang Penetapan Peraturan Pemerintah Pengganti Undang-Undang Nomor 1 Tahun $2016 \quad$ Tentang
Perubahan Kedua Atas Undang-Undang Nomor 23 Tahun $2002 \quad$ Tentang Perlindungan Anak.

2. Pada prinsipnya dalam hukum positif, pengaturan mengenai perlindungan hukum terhadap anak sebagai korban tindak pidana sudah cukup mengaturnya, hal ini dikarenakan bahwa Indonesia melalui Keputusan Presiden Nomor 36 Tahun 1990 telah meratifikasi Konvensi Hak Anak yang mengatur tentang prinsip-prinsip umum perlindungan anak, yaitu nondiskriminasi, kepentingan terbaik bagi anak, kelansungan hidup dan tumbuh berkembang dan menghargai partisipasi anak. Dibentuknya Undang-Undang Nomor 23 Tahun 2002 tentang Perlindungan Anak dan perubahan-perubahannya dimaksudkan sebagai dasar hukum yang secara umum dan menyeluruh mengatur hak-hak anak. Berlakunya pengaturan perlindungan hukum terhadap anak dengan maksud untuk menjamin dan melindungi anak dan hak-haknya agar tetap hidup, tumbuh, berkembang dan berpartisipasi secara optimal sesuai dengan 
harkat dan martabat kemanusiaan, serta mendapat perlindungan dari kekerasan dan diskriminasi.

\section{b. Saran}

Adapun saran yang ingin penulis sampaikan adalah Penulis menyarankan agar pengaturan mengenai Perlindungan Anak beserta Perubahan UndangUndang Perlindungan Anak menjadi dasar hukum bagi aparat penegak hukum dalam bertindak untuk menegakkan dan melindungi hak-hak anak.

\section{DAFTAR PUSTAKA}

Abdussalam, H.R dan Adri Deasasfuryanto. 2014. Hukum Perlndungan Anak. Jakarta: PTIK

Aprilianda, Nurini. Laporan Akhir Pengkajian Hukum Tentang Model Pembinaan Anak Berbasis Pendidikan Layak Anak Dalam Sistem Pemasyarakatan, Pusat Penelitian Dan Pengembangan Sistem Hukum Nasional Badan Pembinaan Hukum Nasional Kementerian Hukum Dan Hak Asasi Manusia Ri 2014.

Ghosita, Arief. 2004. Masalah-Masalah Perlindungan Anak. Jakarta: PT. Bhuana IImu Populer.

Gultom, Maidin. 2012. Perlindungan Hukum Terhadap Anak dan Perempuan. Bandung: Refika Aditama 2013. Perlindungan Hukum terhadap Anak dan Perempuan. Bandung: Refika Aditama.

Prinst, Darwan. 2003. Hukum Anak di Indonesia. Bandung: Citra Aditya Bakti.

Saraswati, Rika. 2015. Hukum Perlindungan Anak di Indonesia. Bandung: Citra Aditya Bakti.
Soe'aidy, Soleh Dan Zulkhair. 2011. Dasar Hukum Perlindungan Anak. Jakarta: CV. Novindo Pustaka Mandiri.

Soemitra. 1990. Aspek Hukum Perlindungan Anak. Jakarta: Bumi Aksara.

Sukardi, Dewa Ketut. 1984. Bimbingan Perkembangan Jiwa Anak. Jakarta: Ghalia Indonesia.

Yuliandri. 2008. Membentuk UndangUndang Yang Berkelanjutan, di dalam: Siti Sundari Rangkuti, Dinamika Hukum Tata Negara dan Hukum Lingkungan (Edisi Khusu Kumpulan Tulisan Dalam Ragka Purnabakti Pror. Dr. Siti Sundari Rangkuti SH). Surabaya: Airlangga University Press.

Komisi Perlindungan Anak Indonesia (KPAI), KPAI Sebut Pelanggaran Hak Anak Terus Meningkat. Diakses pada tanggal 11 Januari 2019 dari http://www.kpai.go.id/berita/kpaisebut-pelanggaran-hak-anak-terusmeningkat.

Republika.co.id. KPAI Terima Pengaduan 4.885 Kasus Anak Selama 2018. Diakses pada tanggal 09 Januari 2019 dari https://www.republika.co.id/berita/n asional/umum/19/01/08/pl0dj1428kpai-terima-pengaduan-4885kasus-anak-selama-2018.

Syahayani, Zihan. Problematika Perppu Kebiri. Diakses pada tanggal 25 Maret 2019 dari http://www.theindonesianinstitute.c om/problematika-perppu-keb 